\title{
Pengujian Model Aplikasi User Interface E-Anjal Dengan Menggunakan Metode Black Box
}

\author{
Yuni Widiastiwi ${ }^{1}$, Ati Zaidiah ${ }^{2}$, Intan Hesti Indriana ${ }^{3}$ \\ Fakultas Ilmu Komputer \\ Universitas Pembangunan Nasional Veteran Jakarta \\ Jl. Rs. Fatmawati, Pondok Labu, Jakarta Selatan, DKI Jakarta, 12450, Indonesia \\ widiastiwi@upnvj.ac.id ${ }^{1}$, atizaidiah@upnvj.ac.id ${ }^{2}, \underline{\text { schembah@gmail.com }}^{3}$
}

\begin{abstract}
Abstrak. Pengujian merupakan salah satu tahapan yang harus dilakukan dalam sebelum melakukan implementasi dari desain model sebuah aplikasi. Tujuan penelitian ini adalah untuk melakukan pengujian terhadap rancangan aplikasi user interface E-Anjal yang telah dibuat untuk melihat kesesuaian dengan model desain yang telah ditentukan dan juga mencari kemungkinan terjadinya kesalahan pada tahap perancangan aplikasi user interface. Metode yang digunakan untuk pengujian menggunakan metode black box, dimana dengan metode ini ingin melihat kesalahan yang terjadi pada rancangan user interface berdasarkan kesesuaian antara output yang dibuat dengan input yang dimasukkan, mengacu kepada model desain aplikasi e-anjal. Hasil yang diharapkan dari penelitian ini adalah tidak adanya kesalahan pada rancangan aplikasi user interface dan sesuai dengan model desain sistem yang telah dibuat.
\end{abstract}

Kata Kunci: Pengujian, Black Box, User Interface, Model E-Anjal

\section{Pendahuluan}

Pengujian perangkat lunak merupakan elemen kritis dari jaminan kualitas perangkat lunak, yang merepresentasikan kajian pokok dari spesifikasi, desain dan pengkodean, dalam hal ini pengujian dilakukan untuk memenuhi persyaratan kualitas dari perangkat lunak [1], proses rekayasa perangkat lunak engineering harus dilakukan pada saat pengujian perangkat lunak[2].

User interface merupakan salah satu desain ragam dialog yang dapat digunakan untuk membantu mempermudah proses komunikasi antara user dengan aplikasi yang dibuat dengan adanya rancangan user interface diharapkan proses komunikasi dan interaksi antara user dengan sistem dapat dilaksanakan dan dilakukan dengan lebih baik.

Perancangan sebuah user interface sudah dilakukan dengan mengacu pada model yang telah dibuat pada tahap awal rancangan desain sistem yaitu pada tahap analisis kebutuhan untuk dapat memodelkan kebutuhan desain sistem informasi anak jalanan terintegrasi untuk komunitas sosial peduli anak jalanan.

Model desain dan model aplikasi user interface pada penelitian sebelumnya telah berhasil dibuat, namun belum dilakukan pengujian untuk melihat kemungkinan terdapatnya kesalahan rancangan aplikasi user interface terhadap keberhasilan dan kesesuaian antara desain model yang telah dibuat.

Dalam melakukan pengujian perangkat lunak dapat dilakukan dengan beberapa pendekatan model pengujian, baik menggunakan model white box testing maupun black box testing. Pada penelitian ini metode yang digunakan dalam pengujian menggunakan blackbox testing hal ini digunakan dengan beberapa pertimbangan bahwa pengujian yang dilakukan ini ingin melihat fungsional dari perangkat lunak yang dibuat, melihat kesesuaian antara model desain dengan rancangan user interface yang telah dibuat.

Penggunaan model metode pengujian black box salah satunya adalah dengan model pencarian kesalahan berdasarkan rancangan aplikasi dari user interface yang telah dibuat pada tahap perancangan model aplikasi.

Setelah aplikasi selesai dibuat, maka perlu dilakukan pengujian untuk memastikan semua proses berjalan sesuai dengan yang diinginkan. Pengujian adalah suatu proses pelaksanaan suatu program dengan tujuan menemukan suatu kesalahan [3], penguji software harus menyiapkan sesi khusus untuk menguji program yang sudah dibuat 
agar kesalahan maupun kekurangan dapat dideteksi sejak awal dan dikoreksi secepatnya [4].

Adapun permasalahan yang ingin dicari dan ditelusuri dalam penelitian ini adalah ingin melakukan pengujian terhadap rancangan aplikasi dari user interface yang telah dibuat, untuk melihat kemungkinan terjadi dan terdapatnya kesalahan serta untuk melihat kesesuaian antara rancangan user interface dengan model desain sistem yang telah dibuat.

Mengacu pada uraian diatas, dapat dirumuskan bahwa tujuan dari penelitian ini adalah melakukan pengujian fungsionalitas dan juga melihat kesesuaian rancangan aplikasi user interface dengan model desain yang ada dengan menggunakan metode black box testing.

\section{Metodologi}

Metodologi berisi tentang tahapan penelitian serta metode yang digunakan dalam pengujian rancangan user interface yang telah dibuat. Metode penelitian digunakan untuk membantu kegiatan penelitian berada dalam jalur yang sudah ditetapkan sehingga pelaksanaan penelitian dapat terarah dan termonitor dengan baik, berikut ini merupakan metodelogi penelitian yang digunakan mengacu kepada Gambar 1, berikut ini:

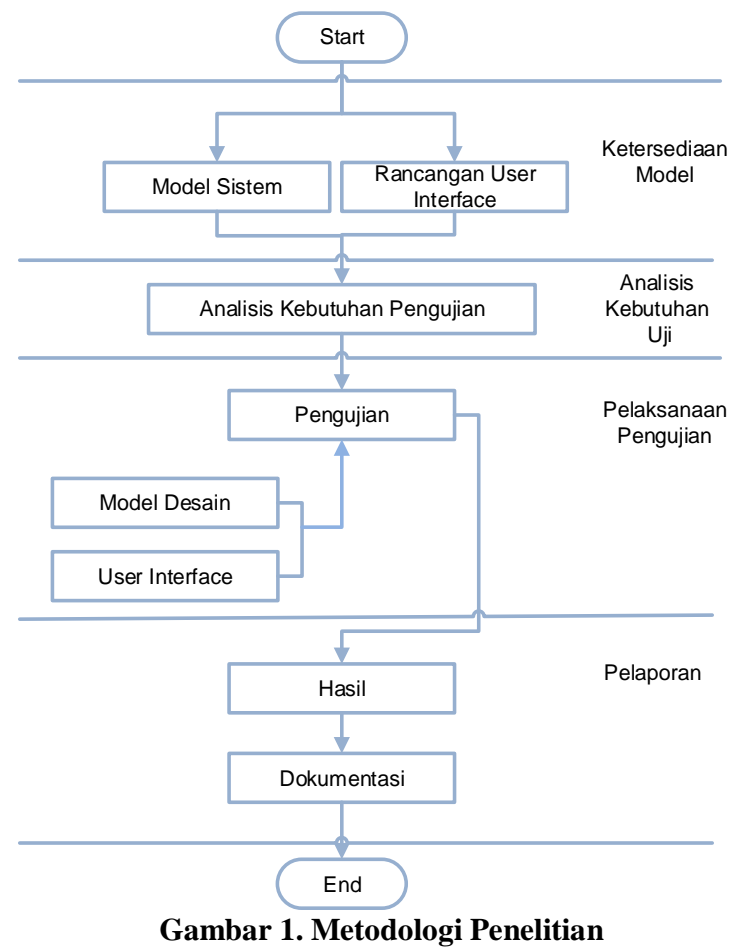

Berikut ini adalah deskripsi dari tahapan yang dilakukan dalam penelitian ini:

1. Tahap Ketersediaan Model, pada tahap ini merupakan tahap keberlanjutan dari hasil penelitian yang telah dilakukan, dimana pada tahap ini ketersediaan antara model sistem dan rancangan user interface sudah ada dan sudah masuk pada tahap desain perancangan aplikasi menggunakan pendekatan berbasis web.

2. Tahap Analisis Kebutuhan Uji, merupakan suatu tahapan dimana dari ketersediaan kedua model sistem yang ada, baik model desain sistem dan model rancangan user interface yang sudah terbentuk, namun masih terdapat kendala dimana masih belum dapat diketahui dan ditentukan apakah kedua model sistem yang ada tersebut sudah berkesesuaian atau belum sesuai dengan rancangan awal yang telah dibuat sebelumnya.

3. Tahap Pelaksanaan Pengujian, merupakan sebuah tahapan yang menjadi inti dari penelitian ini, dimana pada tahapan ini akan menggunakan metode blackbox untuk menerapkan pengujian sistem. Sebelum pelaksanaan pengujian dilakukan, model desain sistem dan juga model rancangan aplikasi user harus terlebih dahulu ada dan dipersiapkan sebagai landasan untuk melakukan pengujian, dimana pada tahap implementasi metode 
blacbox tersebut akan memberikan hasil pengujian apakah sistem rancangan aplikasi user interface sudah sesuai dengan rancangan model yang telah dibuat.

4. Tahap Pelaporan, merupakan tahapan akhir dari pelaksanaan penelitian dimana tahap ini merupakan tahap melakukan dokumentasi dari hasil kegiatan pengujian yang telah berhasil dilakukan, yang dapat digunakan sebagai acuan untuk dapat mengimplementasikan sistem yang telah dirancang.

\section{Hasil Dan Pembahasan}

\subsection{Model Sistem}

Model sistem dibangun menyesuaikan kebutuhan dari komunitas anak jalanan yang ada, aplikasi e-anjal yang terbentuk memiliki dua model pendekatan yaitu model untuk identifikasi dan komunikasi anak jalanan; serta model untuk pembelajaran dengan e-learning. Untuk pembahasan pengujian yang akan dilakukan dibatasi hanya untuk model identifikasi dan komunikasi anak jalanan, adapun model struktur menu dari e-anjal sebagai berikut :

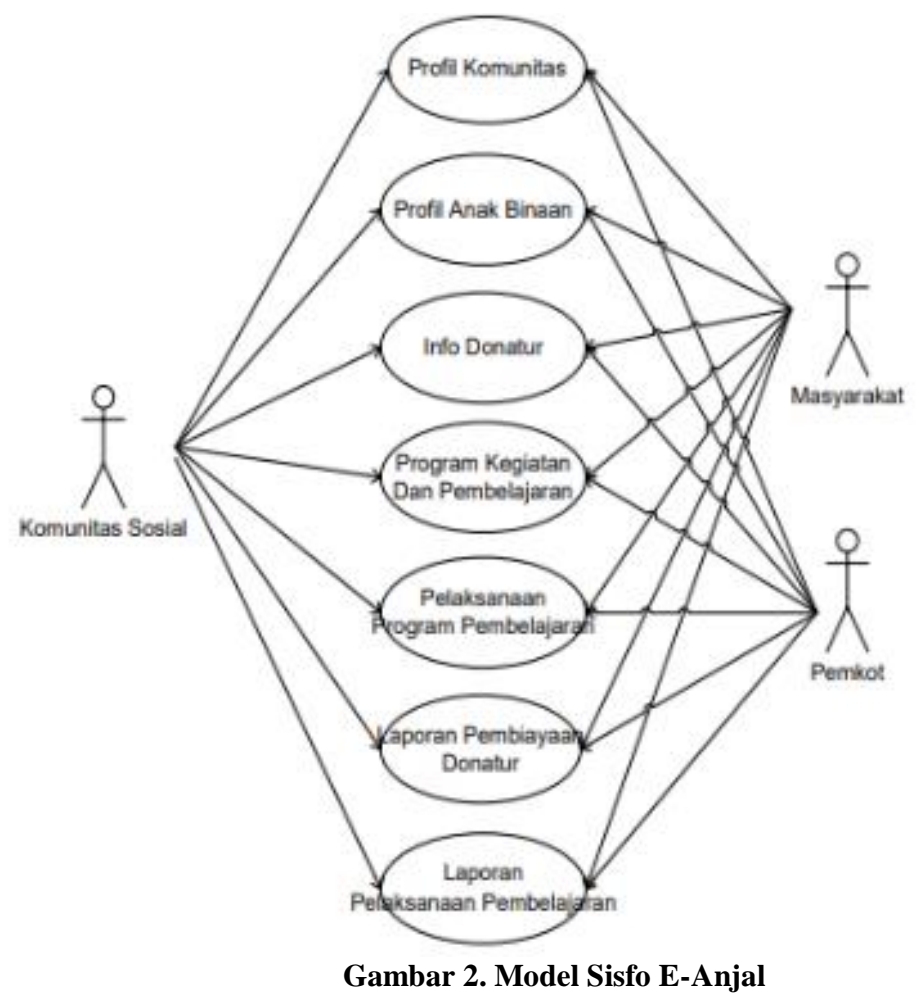

\subsection{Rancangan User Interface}

User interface dirancang sebagai salah satu mekanisme untuk berkomunikasi antara pengguna dengan sistem, model sisfo e-anjal yang dibangun pada gambar 2, sebagai landasan dalam mendesain struktur menu (gambar 3) dan juga mendesain user interface (gambar 3).

Struktur menu yang dibuat merupakan representasi hasil dari pemodelan sistem menggunakan use case diagram, dimana dengan adanya struktur menu akan sangat membantu sebagai landasan dan acuan dalam melakukan desain user interface yang akan dibuat. 


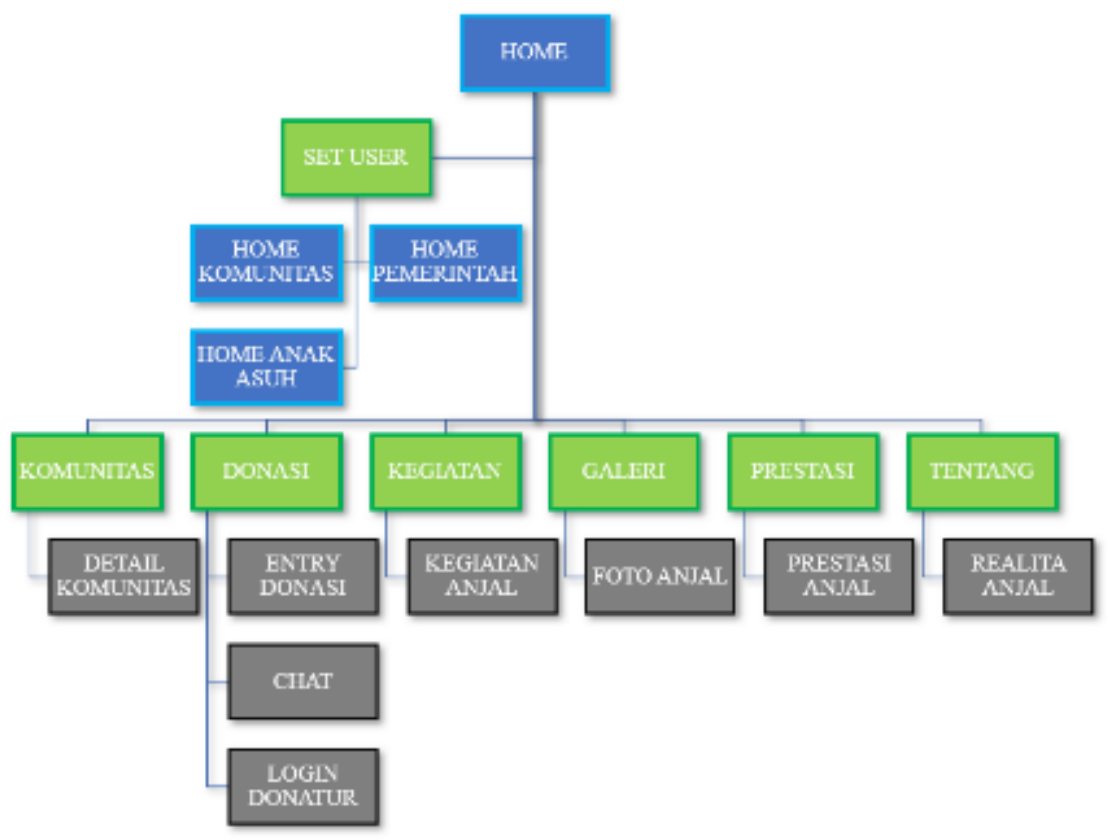

Gambar 3. Struktur Menu

Berdasarkan struktur menu yang dibuat tergambar bahwa terdapat beberapa aktor yang akan terlibat yaitu komunitas, anak asuh, dan pemerintah. Dalam mengoperasikan aplikasi, masig-masing user memiliki otorisasi yang berbeda disesuaikan dengan aturan yang telah ditentukan dan ditetapkan.

Secara umum struktur menu dibagi menjadi 6 (enam) struktur utama yaitu : komunitas, donasi, kegiatan, galeri, prestasi dan tentang. Masinng-masing menu utama didekomposisi menjadi beberapa sub-sub menu yang memberikan detail informasi tentang struktur menu utama.
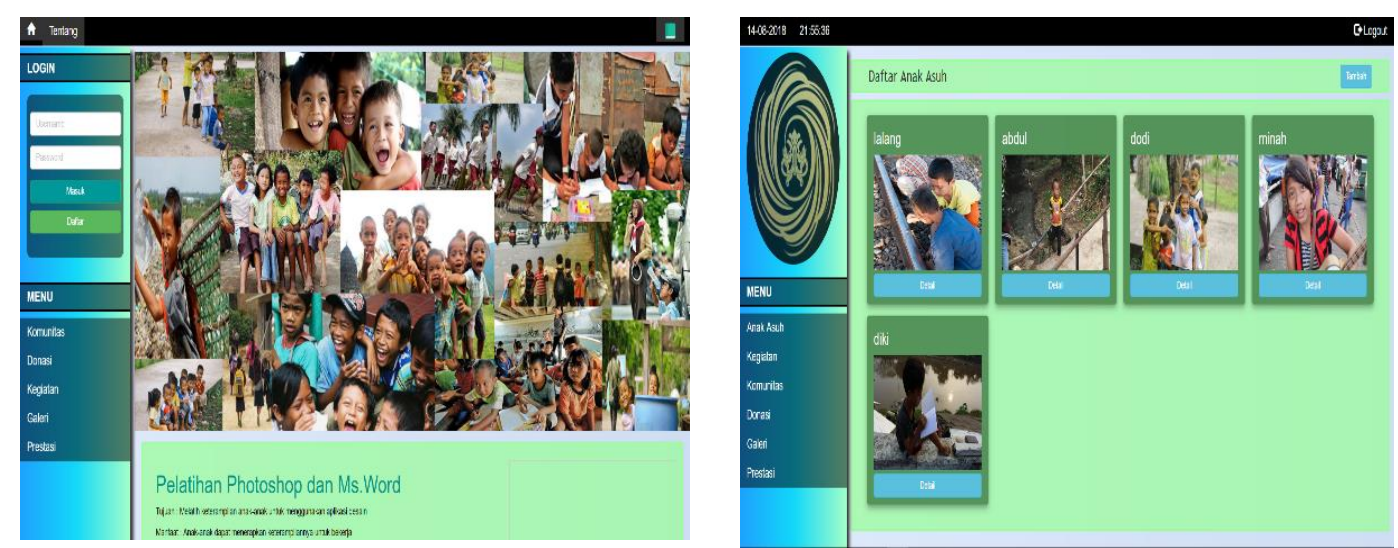

Gambar 4. User Interface 


\subsection{Analisis Kebutuhan Pengujian}

Black Box Testing berfokus pada spesifikasi fungsional dari perangkat lunak. Tester dapat mendefinisikan kumpulan kondisi input dan melakukan pengetesan pada spesifikasi fungsional program [3]. Black Box Testing cenderung untuk menemukan hal-hal berikut:

1. Fungsi yang tidak benar atau tidak ada.

2. Kesalahan antarmuka (interface errors).

3. Kesalahan pada struktur data dan akses basis data.

4. Kesalahan performansi (performance errors).

5. Kesalahan inisialisasi dan terminasi.

Dalam melakukan pengetesan terhadap sebuah sistem, dapat didekati dengan beberapa model cara mendeteksi kesalahan, yaitu :

1. Memeriksa struktur dan kendali internal

2. Memeriksa fungsi dari sebuah user interface

3. Memeriksa sasaran dari desain yang telah dibuat

4. Memeriksa dari permintaan kebutuhan pengguna

5. Memeriksa dengan cara menjalankan program yang dibuat

Pengetesan sistem dilakukan untuk memeriksa kekompakan antara komponen sistem yang diimplementasikan. Tujuan utama dari pengetesan sistem ini adalah untuk memastikan bahwa elemen-elemen atau komponen- komponen dari sistem telah berfungsi sesuai dengan yang diharapkan.Pengetesan perlu dilakukan untuk mencari kesalahan-kesalahan atau kelemahan-kelemahan yang mungkin terjadi [5].

Black Box Testing yang digunakan untuk pengetesan sistem langsung melihat pada rancangan user interface yang sudah dibuat tanpa perlu mengetahui struktur programnya.

\subsection{Pengujian}

Pengujian ini dilakukan hanya untuk melihat kesesuaian antara model desain yang dibuat dengan user interface yang telah dirancang. Berikut ini merupakan tabel hasil pengujian yang telah dilakukan yang tertuang dalam tabel.1

Skenario uji dilakukan dengan melihat kesesuaian antara input yang diaksi dengan output yang dihasilkan berdasarkan aturan dari model yang telah ditetapkan di awal pembuatan sistem, dimana hasil akhir akan memberikan feed back berupa informasi kesimpulan apakah hasil pengujian sudah sesuai atau masih perlu dilakukan perbaikan. 
Tabel 1. Pengujian Aplikasi

\begin{tabular}{|c|c|c|c|c|}
\hline No. & Aktifitas Pengujian & $\begin{array}{ll}\text { Hasil } & \text { Yang } \\
\text { diharapkan } & \end{array}$ & Hasil Pengujian & Kesimpulan \\
\hline '1 & 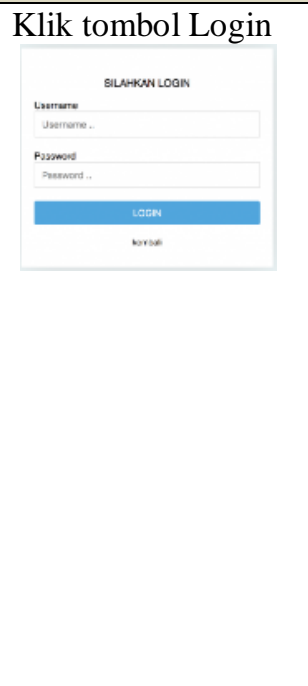 & $\begin{array}{l}\text { Apabila user yang } \\
\text { memiliki otoritas } \\
\text { sebagai admin } \\
\text { melakukan login ke } \\
\text { dalam sistem, maka } \\
\text { user tersebut akan } \\
\text { berhasil masuk ke } \\
\text { dalam aplikasi, } \\
\text { namun apabila user } \\
\text { yang tidak memiliki } \\
\text { otoritas sebagai } \\
\text { admin berusaha } \\
\text { masuk ke dalam } \\
\text { aplikasi maka user } \\
\text { tidak akan berhasil } \\
\text { masuk ke dalam } \\
\text { aplikasi }\end{array}$ & $\begin{array}{l}\text { Masuk dengan menggunakan } \\
\text { user name dan password yang } \\
\text { valid } \rightarrow \text { user berhasil masuk ke } \\
\text { dalam sistem } \\
\text { Masuk menggunakan user name } \\
\text { dan password yang salah } \rightarrow \\
\text { muncul notifikasi login gagal } \\
\text { and }\end{array}$ & $\begin{array}{l}\text { [x] Sesuai } \\
\text { [ ] Perbaiki }\end{array}$ \\
\hline 2 & $\begin{array}{l}\text { Klik tombol Home } \\
\text { Admin }\end{array}$ & $\begin{array}{l}\text { Apabila user yang } \\
\text { memiliki otoritas } \\
\text { sebagai admin } \\
\text { berhasil masuk ke } \\
\text { dalam sistem, maka } \\
\text { otomatis user } \\
\text { tersebut langsung } \\
\text { masuk ke tampilan } \\
\text { menu awal home } \\
\text { admin }\end{array}$ & $\begin{array}{l}\text { Login dengan user admin } \rightarrow \\
\text { tampil menu awal home admin }\end{array}$ & $\begin{array}{l}\text { [x] Sesuai } \\
\text { [ ] Perbaiki }\end{array}$ \\
\hline 3 & $\begin{array}{l}\text { Klik tombol } \\
\text { Pendaftar Baru }\end{array}$ & $\begin{array}{l}\text { Apabila tombol } \\
\text { pendaftar baru di } \\
\text { tekan, maka admin } \\
\text { mampu melakukan } \\
\text { pengelolaan } \\
\text { terhadap otorisasi } \\
\text { komunitas } r \text { baru } \\
\text { yang akan } \\
\text { bergabung. }\end{array}$ & $\begin{array}{l}\text { Tombol pendaftar baru di tekan } \\
\rightarrow \text { admin berhasil mengelola } \\
\text { modul otorisasi komunitas baru } \\
\mathbf{\Omega}\end{array}$ & $\begin{array}{l}\text { [x] Sesuai } \\
\text { [ ] Perbaiki }\end{array}$ \\
\hline 4 & $\begin{array}{l}\text { Klik tombol Anak } \\
\text { Asuh di Admin }\end{array}$ & $\begin{array}{lr}\text { Apabila } & \text { tombol } \\
\text { Anak } & \text { Asuh di } \\
\text { Admin } & \text { ditekan } \\
\text { maka sistem mampu } \\
\text { mengelola data anak } \\
\text { asuh }\end{array}$ & $\begin{array}{l}\text { Tombol komunitas ditekan } \rightarrow \\
\text { admin mampu mengelola data } \\
\text { anak asuh } \\
\mathbf{Q}-1 \\
\\
0 \\
\end{array}$ & $\begin{array}{l}\text { [x] Sesuai } \\
\text { [ ] Perbaiki }\end{array}$ \\
\hline 5 & $\begin{array}{l}\text { Klik tombol User } \\
\text { 출 Usan }\end{array}$ & $\begin{array}{l}\text { Apabila tombol user } \\
\text { ditekan, maka } \\
\text { admin memiliki } \\
\text { kemampuan untuk } \\
\text { melakukan } \\
\text { pengelolaan } \\
\text { terhadap otorisasi } \\
\text { user, komunitas, } \\
\text { kegiatan dan }\end{array}$ & $\begin{array}{l}\text { Tombol user ditekan } \rightarrow \text { admin } \\
\text { berhasil mengelola modul } \\
\text { otorisasi user, komunitas, } \\
\text { kegiatan dan prestasi }\end{array}$ & $\begin{array}{l}\text { [x] Sesuai } \\
\text { [ ] Perbaiki }\end{array}$ \\
\hline
\end{tabular}




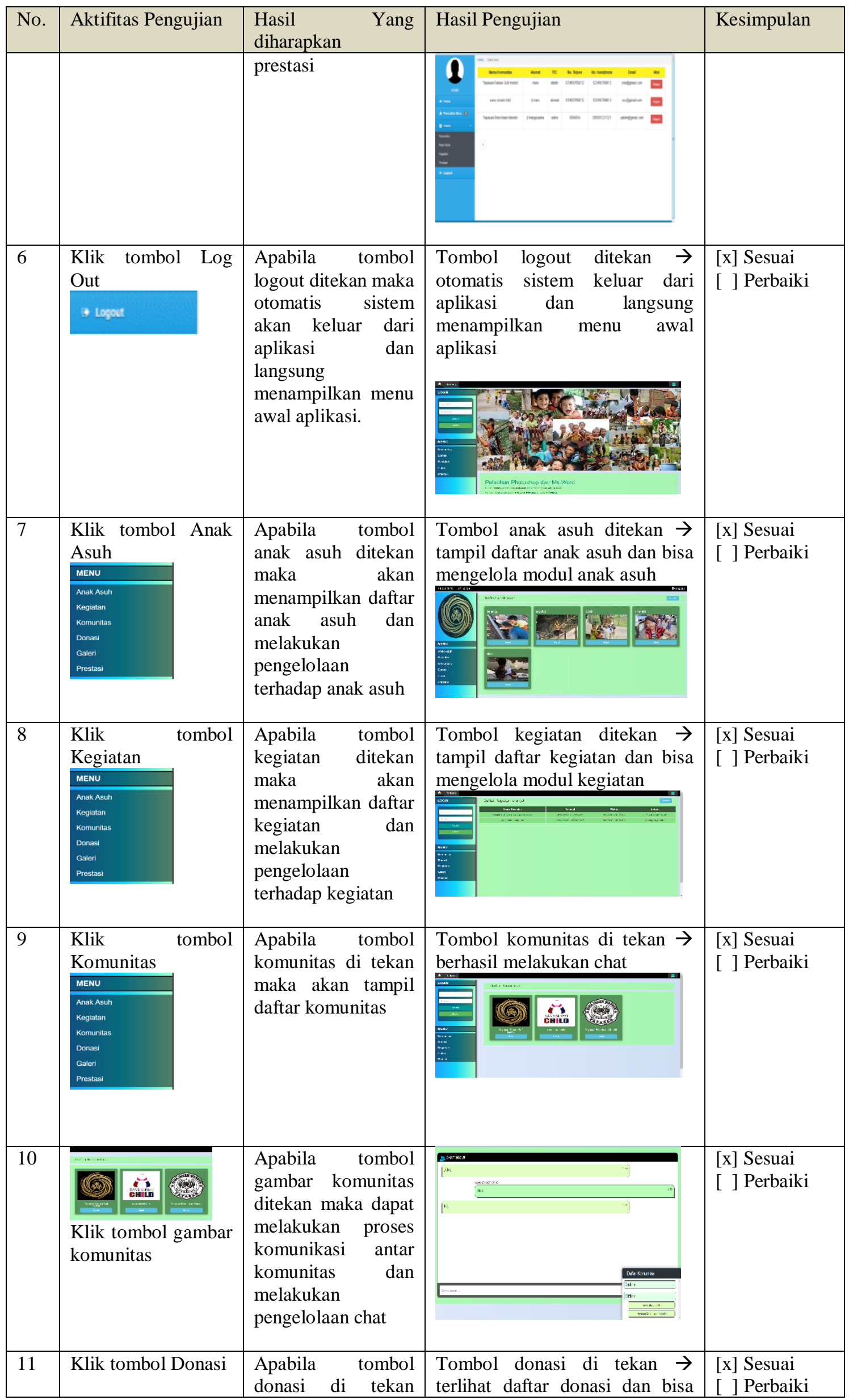




\begin{tabular}{|c|c|c|c|c|}
\hline No. & Aktifitas Pengujian & $\begin{array}{ll}\begin{array}{l}\text { Hasil } \\
\text { diharapkan }\end{array} & \text { Yang } \\
\end{array}$ & Hasil Pengujian & Kesimpulan \\
\hline & $\begin{array}{l}\text { MENU } \\
\text { Anak Asuh } \\
\text { Kegalan } \\
\text { Komuntas } \\
\text { Donasi } \\
\text { Galeri } \\
\text { Prestasi }\end{array}$ & $\begin{array}{l}\text { maka akan terlihat } \\
\text { daftar donasi dan } \\
\text { melakukan } \\
\text { pengelolaan } \\
\text { terhadap donasi }\end{array}$ & $\begin{array}{l}\text { mengelola modul donasi } \\
\text { (2) }\end{array}$ & \\
\hline 12 & $\begin{array}{l}\text { Klik tombol Galeri } \\
\text { MENU } \\
\text { Anak Asut } \\
\text { Kegalatan } \\
\text { Komuntas } \\
\text { Donats } \\
\text { Galer } \\
\text { Prestasi } \\
\end{array}$ & $\begin{array}{lr}\text { Apabila tombol } & \text { toma } \\
\text { galeri di tekan maka } & \text { ditampilkan } \\
\text { akan telah } & \text { berbagai kegiatan } \\
\text { yang oleh } & \\
\text { dilakukan dan } & \text { masing-masing } \\
\text { komunitas } & \\
\text { melakukan } & \\
\text { pengelolaan } & \\
\text { terhadap galeri }\end{array}$ & $\begin{array}{l}\text { Tombol galeri di tekan } \rightarrow \text { tampil } \\
\text { galeri kegiatan dan bisa } \\
\text { mengelola modul galeri }\end{array}$ & $\begin{array}{l}\text { [x] Sesuai } \\
\text { [ ] Perbaiki }\end{array}$ \\
\hline 13 & \begin{tabular}{l|} 
Klik tombol Prestasi \\
MENU \\
Anak Asuh \\
Kegalan \\
Komuntas \\
Donasi \\
Galeri \\
Prestasi \\
\end{tabular} & $\begin{array}{lr}\text { Apabila } & \text { tombol } \\
\text { prestasi di } & \text { tekan } \\
\text { maka } & \text { akan } \\
\text { ditampilkan } & \\
\text { berbagai } & \text { prestasi } \\
\text { yang } & \text { telah } \\
\text { dilakukan } & \text { oleh } \\
\text { masing-masing } & \\
\text { komunitas dan } & \text { delakukan } \\
\text { pengelolaan } & \\
\text { terhadap prestasi. }\end{array}$ & $\begin{array}{l}\text { Tombol prestasi di tekan } \rightarrow \\
\text { tampil daftar prestasi dan bisa } \\
\text { mengelola modul prestasi } \\
\end{array}$ & $\begin{array}{l}\text { [x] Sesuai } \\
\text { [ ] Perbaiki }\end{array}$ \\
\hline 14 & $\begin{array}{l}\text { Klik tombol donasi } \\
\text { di menu donasi } \\
\text { PPiln Donasi } \\
\text { Pill Donasi }\end{array}$ & $\begin{array}{lr}\text { Apabila } & \text { tombol } \\
\text { pilih donasi di tekan } \\
\text { maka } & \text { akan } \\
\text { ditampilkan } & \text { form } \\
\text { donasi } & \end{array}$ & $\begin{array}{l}\text { Tombol pilih donasi di tekan } \rightarrow \\
\text { tampil form donasi }\end{array}$ & $\begin{array}{l}\text { [x] Sesuai } \\
\text { [ ] Perbaiki }\end{array}$ \\
\hline 15 & $\begin{array}{l}\text { Klik tombol mode } \\
\text { Donasi } \\
\text { Pilih Mode Donasi }\end{array}$ & $\begin{array}{l}\text { Apabila tombol } \\
\text { mode donasi di } \\
\text { tekan maka akan } \\
\text { ditampilkan form } \\
\text { mode donasi }\end{array}$ & 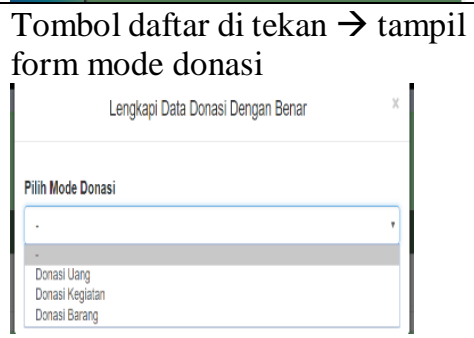 & $\begin{array}{l}\text { [x] Sesuai } \\
\text { [ ] Perbaiki }\end{array}$ \\
\hline 16 & $\begin{array}{l}\text { Klik tombol Daftar } \\
\text { Sudah Daftar }\end{array}$ & $\begin{array}{lr}\begin{array}{l}\text { Apabila } \\
\text { daftar di }\end{array} & \begin{array}{r}\text { tombol } \\
\text { maka }\end{array} \\
\text { ditampilkan } & \text { form } \\
\text { pendaftaran } & \text { untuk } \\
\text { bergabung } & \text { sebagai } \\
\text { komunitas } & \text { yang } \\
\text { terintegrasi } & \text { dalam } \\
\text { sistem. } & \end{array}$ & $\begin{array}{l}\text { Tombol daftar di tekan } \rightarrow \text { tampil } \\
\text { form pendaftaran }\end{array}$ & $\begin{array}{l}\text { [x] Sesuai } \\
\text { [ ] Perbaiki }\end{array}$ \\
\hline
\end{tabular}




\begin{tabular}{|c|c|c|c|c|}
\hline No. & Aktifitas Pengujian & $\begin{array}{ll}\text { Hasil } & \text { Yang } \\
\text { diharapkan } & \\
\end{array}$ & Hasil Pengujian & Kesimpulan \\
\hline 17 & $\begin{array}{l}\text { Klik tombol } \\
\text { Komunitas } \\
\text { Komunitas }\end{array}$ & $\begin{array}{l}\text { Apabila tombol } \\
\text { komunitas di tekan, } \\
\text { maka akan } \\
\text { ditampilkan daftar } \\
\text { komunitas dan juga } \\
\text { detail dari masing- } \\
\text { masing komunitas. }\end{array}$ & $\begin{array}{l}\text { Tombol komunitas di tekan, } \rightarrow \\
\text { tampil daftar komunitas dan } \\
\text { detailnya }\end{array}$ & $\begin{array}{l}\text { [x] Sesuai } \\
\text { [ ] Perbaiki }\end{array}$ \\
\hline 18 & $\begin{array}{l}\text { Klik tombol Donasi } \\
\text { Pilih Donasi }\end{array}$ & $\begin{array}{lr}\text { Apabila } & \text { tombol } \\
\text { donasi di tekan, } & \text { akan } \\
\text { maka } & \text { menu } \\
\text { ditampilkan } & \text { chat } \\
\text { donasi dan } & \text { dapat } \\
\text { yang oleh } \\
\text { dilakukan dapat } \\
\text { donatur untuk dant } \\
\text { berkomunikasi } \\
\text { langsung dengan } \\
\text { pengelola } \\
\text { komunitas }\end{array}$ & $\begin{array}{l}\text { Tombol donasi di tekan } \rightarrow \\
\text { tampil menu donasi dan chat }\end{array}$ & $\begin{array}{l}\text { [x] Sesuai } \\
\text { [ ] Perbaiki }\end{array}$ \\
\hline 19 & $\begin{array}{l}\text { Klik tombol tambah } \\
\text { Galeri } \\
\text { Tambah }\end{array}$ & $\begin{array}{lr}\text { Apabila } & \text { tombol } \\
\text { galeri di } & \begin{array}{r}\text { tekan, } \\
\text { akan }\end{array} \\
\text { maka } & \text { form } \\
\text { ditampilkan } & \text { untuk menambah } \\
\text { foto kegiatan }\end{array}$ & $\begin{array}{l}\text { Tombol galeri di tekan } \rightarrow \text { tampil } \\
\text { form untuk menambah foto } \\
\text { kegiatan }\end{array}$ & $\begin{array}{l}\text { [x] Sesuai } \\
\text { [ ] Perbaiki }\end{array}$ \\
\hline 20 & $\begin{array}{l}\text { Klik tombol tambah } \\
\text { Anak Asuh } \\
\text { Tambah }\end{array}$ & $\begin{array}{l}\text { Apabila tombol } \\
\text { tambah Anak Asuh } \\
\text { di tekan, maka akan } \\
\text { ditampilkan form } \\
\text { Anak Asuh }\end{array}$ & $\begin{array}{l}\text { Tombol tambah Anak Asuh } \\
\text { di tekan } \rightarrow \text { tampil form untuk } \\
\text { menambah Anak Asuh }\end{array}$ & \\
\hline 21 & $\begin{array}{l}\text { Klik tombol Info } \\
\text { Detail Anak Asuh } \\
\text { Info Detail Anak Asuh }\end{array}$ & $\begin{array}{l}\text { Apabila tombol Info } \\
\text { Detail Anak Asuh di } \\
\text { tekan, maka akan } \\
\text { ditampilkan form } \\
\text { Info Detail Anak } \\
\text { Asuh }\end{array}$ & $\begin{array}{l}\text { Tombol Info Detail Anak Asuh } \\
\text { di tekan } \rightarrow \text { tampil form Info } \\
\text { Detail Anak Asuh }\end{array}$ & \\
\hline 22 & Klik tombol tambah & Apabila & Tombol prestasi di tekan $\rightarrow$ & [x] Sesuai \\
\hline
\end{tabular}




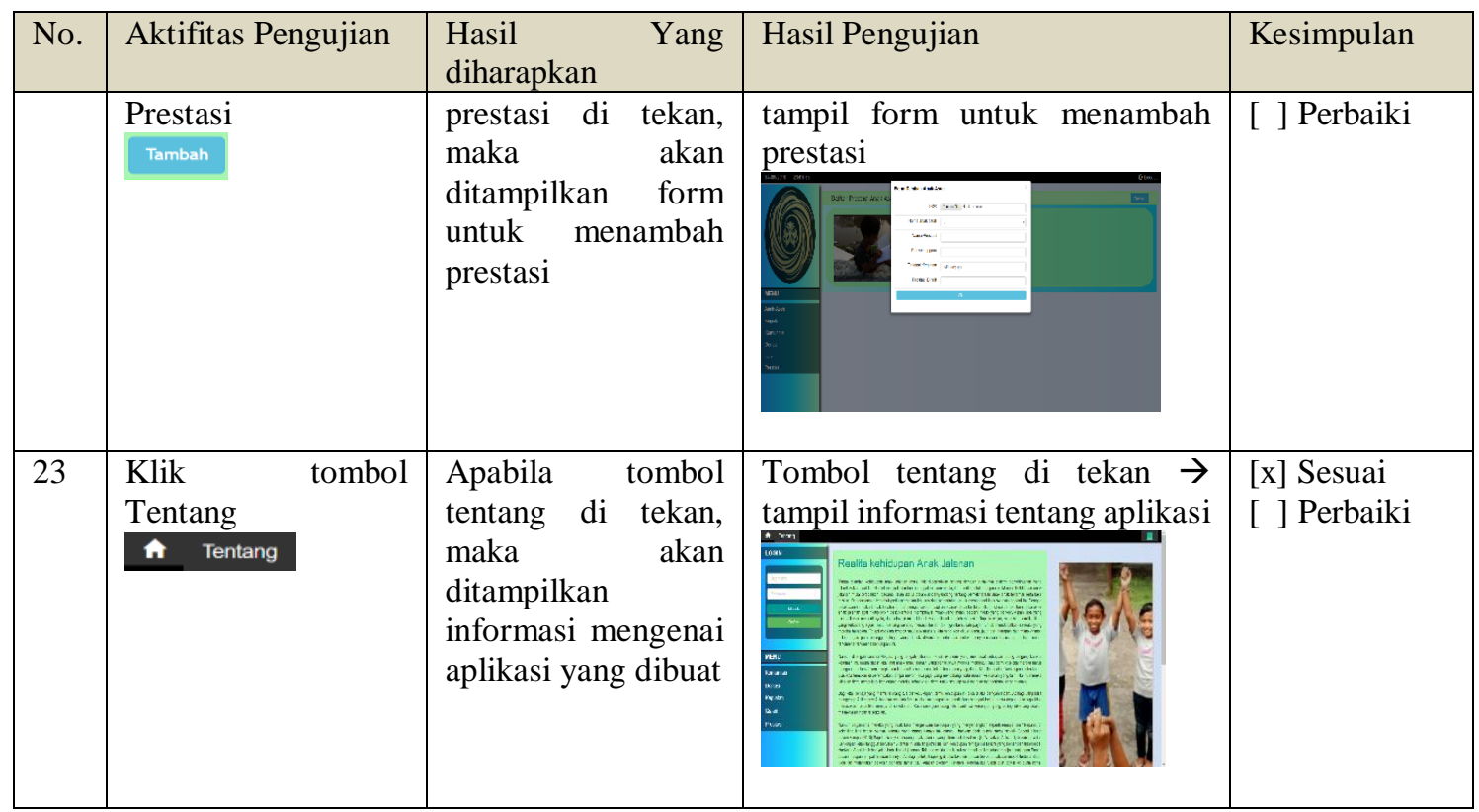

Berdasarkan tabel 1 tersebut di atas, didapatkan informasi bahwa hasil dari pengujian terhadap sistem yang dibuat sudah sesuai dengan model yang telah ditentukan dan ditetapkan saat awal melakukan perancangan sistem, dimana terdapat kesesuaian antara rancangan aplikasi user interface yang dibuat dengan desain model sistemnya. Berdasarkan informasi tersebut, maka dapat menjadi dasar bahwa apabila aplikasi sudah melewati tahapan pengujian dan sudah sesuai dengan model yang telah ditentukan dan dibuat, maka aplikasi tersebut sudah siap untuk dapat diimplementasikan serta digunakan oleh pengguna.

\section{Simpulan}

Model desain sistem dan model desain user interface pada penelitian sebelumnya telah berhasil dibuat, namun belum dilakukan pengujian terhadap keberhasilan dan kesesuaian antara desain model system dengan user interface yang telah dibuat.

Untuk melihat kesesuaian antara rancangan aplikasi user interface yang dibuat dengan model desain sistem yang telah dibuat, maka dilakukan pengujian sistem dengan menggunakan metode blackbox testing.

Hasil dari pengujian yang telah dilakukan dapat disimpulkan bahwa terdapat kesesuaian antara rancangan user interface yang dibuat dengan model yang telah dirancang sebelumnya.

\section{REFERENSI}

[1] G. W. Setiawan, "Pengujian Perangkat Lunak Menggunakan Metode Black Box Studi Kasus Exelsa Universitas Sanata Dharma," p. 286, 2011.

[2] M. Nurudin, W. Jayanti, R. D. Saputro, M. P. Saputra, and Y. Yulianti, "Pengujian Black Box pada Aplikasi Penjualan Berbasis Web Menggunakan Teknik Boundary Value Analysis," J. Inform. Univ. Pamulang, vol. 4, no. 4, p. 143, 2019, doi: 10.32493/informatika.v4i4.3841.

[3] M. S. Mustaqbal, R. F. Firdaus, and H. Rahmadi, "Pengujian Aplikasi Menggunakan Black Box Testing Boundary Value Analysis (Studi Kasus : Aplikasi Prediksi Kelulusan SNMPTN),” vol. I, no. 3, pp. 31-36, 2015.

[4] T. Hidayat and M. Muttaqin, "Pengujian Sistem Informasi Pendaftaran dan Pembayaran Wisuda Online menggwiunakan Black Box Testing dengan Metode Equivalence Partitioning dan Boundary Value Analysis," J. Tek. Inform. UNIS JUTIS, vol. 6, no. 1, pp. 2252-5351, 2018, [Online]. Available: www.ccssenet.org/cis.

[5] H. B. I. Alfaris, C. Anam, and A. Masy'an, "Implementasi Black Box Testing Pada Sistem Informasi Pendaftaran Santri Berbasis Web Dengan Menggunakan PHP Dan MYSQL,” J. Sains dan Teknol., vol. 6, no. 1, pp. 23-38, 2016, [Online]. Available: http://ejournal.unwaha.ac.id/index.php/saintek/article/download/64/64. 